\title{
The Political Economy of Mountain Java
}





\section{The Political Economy of Mountain Java}

An Interpretive History

Robert W. Hefner

UNIVERSITY OF CALIFORNIA PRESS

Berkeley Los Angeles London 


\title{
For My Parents
}

\author{
University of California Press \\ Berkeley and Los Angeles, California \\ University of California Press, Ltd. \\ London, England \\ - 1990 by
}

The Regents of the University of California

\section{Library of Congress Cataloging-in-Publication Data}

Hefner, Robert W., 1952-

The political economy of mountain Java : an interpretive history / Robert W. Hefner.

p. cm.

Includes bibliographical references.

ISBN 0-520-08269-9

1. Rural development-Indonesia-Tengger Mountains Region (Java)

2. Tengger Mountains Region (Java, Indonesia)-Social conditions.

3. Java (Indonesia)-Economic conditions-Regional disparities.

I. Title.

HN710.Z9C611454 1990

$307.1^{\prime} 412^{\prime} 095982-\mathrm{dc} 20$

Printed in the United States of America

$$
\begin{array}{lllllllll}
1 & 2 & 3 & 4 & 5 & 6 & 7 & 8 & 9
\end{array}
$$

The paper used in this publication meets the minimum requirements of American National Standard for Information Sciences-Permanence of Paper for Printed Library Materials, ANSI Z39.48-1984. 